\title{
Training Ice Breaking bagi Guru Madrasah Ibtidaiyah (MI) Silahul Muslimin Dusun Persen Desa Kedungasri Kecamatan Tegaldlimo Kabupaten Banyuwangi
}

\author{
Iis Daniati Fatimah*1, Novialita Angga Wiratama² \\ 1,2Pendidikan Guru Sekolah Dasar, Universitas PGRI Ronggolawe, Indonesia \\ *e-mail: iisdaniati@gmail.com ${ }^{1}$, novialita3@gmail.com ${ }^{2}$
}

\begin{abstract}
Abstrak
Ice breaking merupakan sentuhan aktivitas yang dapat digunakan untuk memecahkan kebekuan, kekalutan, kejemuan dan kejenuhan suasana sehingga menjadi mencair dan suasana bisa kembali pada keadaan semula (lebih kondusif). Jika sentuhan aktivitas ini diterapkan pada proses pembelajaran di kelas, maka besar kemungkinannya siswa kembali pada kondisi (semangat melakukan belajar dan mempunyai motivasi dalam belajar). Kejenuhan belajar dapat melanda seorang siswa yang kehilangan motivasi dan konsolidasi salah satu tingkat ketrampilan tertentu sebelum sampai pada tingkat ketrampilan berikutnya. Tujuan dari program pengabdian kepada masyarakat ini adalah memberikan pelatihan guru MI Silahul Muslimin Dusun Persen Desa Kedungasri Kecamatan Tegaldlimo Kabupaten Banyuwangi. Pelatihan dilakukan dengan mengenalkan berbagai jenis ice breaking dan pelatihan penerapannya. Jenis Ice breaking yang dilatihkan terhadap para guru diantaranya Ice breaking jenis permainan atau game berupa permainan tepuk, yel dan senam.
\end{abstract}

Kata kunci: Ice Breaking, Jenis-Jenis Ice Breaking, Pelatihan

\section{Abstract}

Ice breaking is a touch of activity that can be used to break the ice, confusion, boredom and saturation of the atmosphere so that it melts and the atmosphere can return to its original state (more conducive). If the touch of this activity is applied to the learning process in the classroom, it is very likely that students will return to their condition (spirit in learning and have motivation in learning). Learning saturation can hit a student who loses motivation and consolidates one particular skill level before arriving at the next skill level. The purpose of this community service program is to provide training for MI Silahul Muslimin Dusun Persen, Kedungasri Village, Tegaldlimo District, Banyuwangi Regency. The training was carried out by introducing various types of ice breaking and training on their application. The types of ice breaking that are trained for the teachers include ice breaking games or games in the form of clapping, yelling and gymnastic.

Keywords: Ice Breaking, Training, Types of Ice breaking

\section{PENDAHULUAN}

Proses belajar mengajar dapat diartikan sebagai suatu interaksi antara siswa dan guru dalam rangka mencapai tujuannya. Interaksi yang terjadi seharusnya tidak berlangsung hanya dari satu arah, tetapi terjadi secara dua arah yaitu terjadinya timbal balik antara siswa dengan guru. Guru dan siswa dalam proses pembelajaran berperan aktif. Dalam proses kegiatan belajar guru memiliki peran yang sangat penting. Sebagai guru sudah seharusnya mengorganisasikan lingkungan belajar yang kondusif, nyaman dan menciptakan suasana belajar yang hangat agar siswa dapat belajar dengan nyaman. Menurut (Tohirin,2011) belajar merupakan suatu proses yang dilakukan individu memperoleh suatu perubahan tingkah laku yang baru secara keseluruhan, sebagai hasil pengalaman individu itu sendiri dalam interaksi dengan lingkungannya. Kegiatan pembelajaran di masa pandemi ini dilakukan secara tatap muka terbatas (PTM). Hasil observasi di sekolah MI Silahul Muslimin Dusun Persen Desa Kedungasri Kecamatan Tegaldlimo Kabupaten Banyuwangi. Pembelajaran tatap muka terbatas tahun pelajaran 2021/2022 harus mengacu pada SKB empat menteri. Melalui SKB Empat Menteri yang dirilis pada 30 Maret 2021, pemerintah telah menetapkan bahwa pemerintah pusat, pemerintah 
daerah, kanwil, atau kantor Kemenag mewajibkan satuan pendidikan yang para guru dan tenaga pendidiknya sudah divaksinasi secara lengkap untuk segera menyediakan layanan PTM.

Pembelajaran selama pandemi covid19 dilakukan dalam tatap muka terbatas (PTM) dan menggunakan metode drilling. Kegiatan awal pembelajaran guru hanya memberikan apersepsi, guru belum melakukan motivasi terhadap siswa. Ketika proses pembelajaran berlangsung siswa lebih banyak melakukan aktifitas mengerjakan soal yang diberikan guru. Jika beberapa siswa telah menyelesaikan tugasnya terlihat tidak ada kegiatan hanya dihimbau untuk menunggu teman yang belum selesai. Terlihat siswa ada yang melamun, atau sesekali menggangu teman yang belum selesai mengerjakan tugas. Sehingga dalam mengikuti pembelajaran siswa sering mengalami kebosanan dan kurang bersemangat dan cenderung pasif.

Menurut (Muhibbin,2013) menyatakan bahwa kejenuhan belajar ialah rentang waktu tertentu yang digunakan untuk belajar, tetapi tidak mendapatkan hasil. Seorang siswa yang mengalami kejenuhan belajar merasa seakan-akan pengetahuan dan kemampuan yang diperoleh dari belajar tidak ada kemajuan dan hasil belajar pada umumnya yang tidak berlangsung selamanya. Tetapi dalam waktu rentang tertentu saja, misalnya seminggu. Namun tidak sedikit siswa yang mengalami rentang waktu yang membawa kejenuhan itu berkali-kali dalam satu periode belajar tertentu. Teknik yang dapat digunakan untuk mengatasi kejenuhan belajar para siswa adalah dengan menerapkan ice breaking. (Fanani,2010) menyatakan bahwa ice breaking merupakan sentuhan aktivitas yang dapat digunakan untuk memecahkan kebekuan, kekalutan, kejemuan dan kejenuhan suasana sehingga menjadi mencair dan suasana bisa kembali pada keadaan semula (lebih kondusif). Jika sentuhan aktivitas ini diterapkan pada proses pembelajaran di kelas, maka besar kemungkinannya siswa kembali pada kondisi (semangat melakukan belajar dan mempunyai motivasi dalam belajar). Kejenuhan belajar dapat melanda seorang siswa yang kehilangan motivasi dan konsolidasi salah satu tingkat ketrampilan tertentu sebelum sampai pada tingkat ketrampilan berikutnya. Menurut (Setyawan,2013) Ice breaking bukan menjadi tujuan utama dalam pembelajaran, namun merupakan pendukung utama dalam menciptakan suasana pembelajaran yang efektif.

Tujuan utama ice breaking adalah meningkatkan motivasi siswa dalam mengikuti proses pembelajaran. Dengan adanya ice breaking diharapkan siswa yang belum termotivasi untuk mengikuti pembelajaran menjadi termotivasi, atau siswa yang sudah jenuh mengikuti proses pembelajaran dapat kembali kepada performa awal sebagaimana saat awal pembelajaran yang penuh motivasi.

\section{METODE}

Metode pelaksanaan yang akan dilakukan dalam kegiatan pengabdian kepada masyarakat ini yaitu:

\subsection{Tahap Persiapan}

Tahap persiapan melakukan kegiatan observasi di lapangan dan wawancara langsung dilakukan terhadap mitra yaitu Guru MI Silahul Muslimin Dusun Persen Desa Kedungasri Kecamatan Tegaldlimo Kabupaten Banyuwangi untuk mendapatkan data dan permasalahan akurat yang dialami oleh mitra sebagai bahan refleksi. Observasi dilakukan untuk menentukan solusi dan alternatif dalam memecahkan permasalahan yang dihadapi mitra. Kegiatan wawancara langsung dilakukan terhadap mitra untuk mendapatkan data dan permasalahan akurat yang dialami oleh mitra sebagai bahan refleksi. Observasi dilakukan untuk menentukan solusi dan alternatif dalam memecahkan permasalahan yang dihadapi mitra.

Tahap persiapan ini difokuskan untuk menyiapkan semua keperluan Training Ice Breaking. Pada tahap persiapan ini yang dilakukan adalah:

a. Survei ke MI Silahul Muslimin Dusun Persen Desa Kedungasri Kecamatan Tegaldlimo Kabupaten Banyuwangi

b. Penentuan lokasi dan sasaran berdasarkan hasil survei.

c. Penyusunan bahan/materi pelatihan, yang meliputi: slide power point untuk kegiatan 


\section{Training Ice Breaking}

d. Survei MI Silahul Muslimin Dusun Persen Desa Kedungasri Kecamatan Tegaldlimo Kabupaten Banyuwangi.

\subsection{Tahap Pelaksanaan}

Pada tahap pelaksanaan, hal-hal yang dilakukan meliputi:

a. Penjelasan tentang Ice Breaking

b. Pelatihan penerapan Ice Breaking dalam pembelajaran

c. Melakukan evaluasi terhadap hasil pelatihan dan pendampingan.

Hasil dokumentasi kegiatan pengabdian kepada masyarakat terhadap para guru Madrasah Ibtidaiyah (MI) Silahul Muslimin Dusun Persen Desa Kedungasri Kecamatan Tegaldlimo Kabupaten Banyuwangi sebagai berikut:

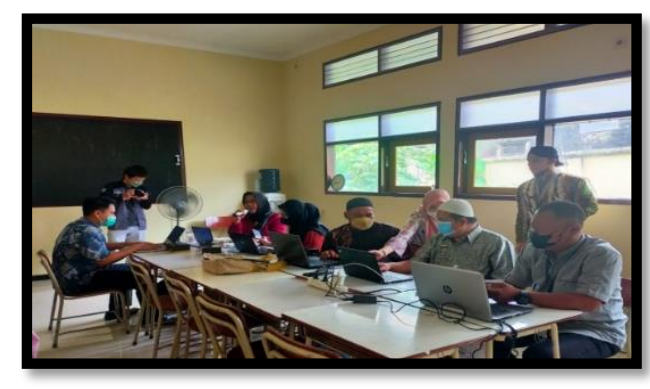

(a)

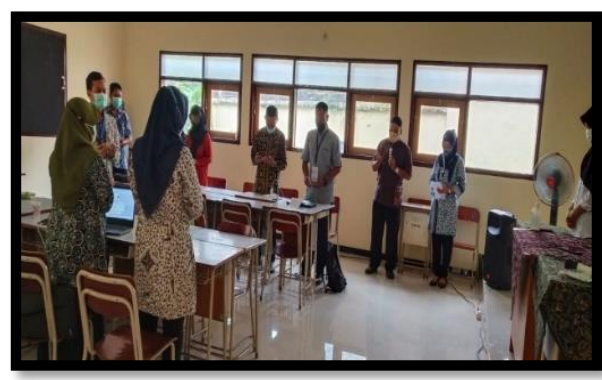

(b)

Gambar 1. Dokumentasi Kegiatan Pengabdian Kepada Masyarakat

Pada gambar a di atas merupakan kegiatan para guru melakukan diskusi sebelum menerapkan simulasi ice breaking sedangkan pada gambar b merupakan kegiatan para guru melakukan simulasi ice breaking. Semua peserta nampak antusias dalam mengikuti setiap kegiatan.

\section{HASIL DAN PEMBAHASAN}

\subsection{Pemaparan Materi Pelatihan}

Pengabdian pada masyarakat dengan judul training ice breaking bagi Guru Madrasah Ibtidaiyah (MI) Silahul Muslimin Dusun Persen Desa Kedungasri Kecamatan Tegaldlimo Kabupaten Banyuwangi. Peserta pelatihan ini adalah para guru MI Silahul Muslimin sebanyak 15 guru.

Kegiatan pelatihan diawali dengan memberikan pemaparan materi mengenai ice breaking. Pelatihan ini merupakan upaya memberikan wawasan, informasi dan pengalaman menciptakan suatu kondisi belajar yang kondusif dan aktif. (Said,2010) mengungkapkan, ice breaking adalah permainan atau kegiatan yang berfungsi untuk mengubah suasana kebekuan dalam kelompok. Pendapat lain dikemukakan oleh (Sunarto,2012) ice breaking dalam pembelajaran dapat diartikan sebagai pemecah situasi kebekuan fikiran atau fisik siswa. Ice breaking juga dimaksudkan untuk membangun suasana belajar yang dinamis, penuh semangat dan antusiasme. Hubungan antara motivasi dengan ice breaking dapat dilihat dari tujuan utamanya yaitu meningkatkan motivasi siswa dalam aktivitas selama proses pembelajaran. Ada beberapa manfaat melakukan aktivitas ice breaking, diantaranya adalah:

a. Menghilangkan kebosanan, kejemuan, kecemasan, dan keletihan karena bisa keluar sementara dari rutinitas pelajaran dengan melakukan aktivitas gerak bebas dan ceria.

b. Melatih berpikir secara kreatif dan luas siswa.

c. Mengembangkan dan mengoptimalkan otak dan kreativitas siswa.

d. Melatih siswa berinteraksi dalam kelompok dan bekerja sama dalam satu tim.

e. Melatih berpikir sistimatis dan kreatif untuk memecahkan masalah. 
f. Meningkatkan rasa percaya diri.

g. Melatih menentukan strategi secara matang.

h. Melatih kreativitas dengan bahan yang terbatas.

i. Melatih konsentrasi, berani bertindak dan tidak takut salah.

j. Merkatkan hubungan interpersonal yang renggang.

k. Melatih untuk menghargai orang lain.

l. Memantapkan konsep diri.

m. Melatih jiwa kepemimpinan.

n. Melatih bersikap ilmiah

\subsection{Pelatihan Ice Breaking}

Pelaksanaan pelatihan ice breaking di MI Silahul Muslimin Dusun Persen Desa Kedungasri Kecamatan Tegaldlimo Kabupaten Banyuwangi diawali dengan pemaparan materi dari modul yang telah disiapkan dan dibagikan pada para peserta pelatihan. Setelah kegiatan pemaparan dan sesi tanya jawab kegiatan pelatihan selanjutnya adalah praktik ice breaking oleh para peserta. Simulasi praktik ini dilakukan setiap peserta secara individual. Ice breaking dapat dilakukan dengan berbagai macam cara atau permainan. Menurut (Yonny,2012) bentuk ice breaking ada bermacam-macam, mulai dari sekadar teka-teki, cerita-cerita lucu atau humor ringan yang memancing senyum, lagu-lagu atau nyanyian yang disertai gerakan tubuh (action song), sampai permainan-permainan berkelompok yang cukup menguras tenaga atau bahkan pikiran. Selain itu dapat juga dilakukan dengan melakukan senam otak (brain gym). Dalam pelatihan di MI Silahul Muslimin Dusun Persen Desa Kedungasri Kecamatan Tegaldlimo Kabupaten Banyuwangi ice breaking yang dilatihkan berupa yel-yel, tepuk tangan, game.

Yel-Yel merupakan ungkapan penyemangat. Yel-yel biasa diungkapkan secara berkelompok dengan beragam kata dan gaya. Masing-masing kelompok biasanya akan menampilkan yel-yel yang berbeda atau sesuai dengan karakteristiknya dengan gaya yang lucu, unik, dan energik. Yel-yel ini meskipun terkesan sederhana namun memiliki tingkat pemulih konsentrasi yang tepat. Yel-yel tidak membutuhkan waktu lama untuk melakukannya. Ratarata hanya membutuhkan durasi waktu 3-5 menit. Membuat yel-yel tidak perlu susah-susah. Yel-yel dapat dibuat dengan kata-kata sendiri atau mencuplik dari sebuah lagu. Yang penting saat melakukan yel-yel harus dilakukab dengan kompak dan riang gembira. Yel sangat efektif dalam menyiapkan aspek psikologis siswa untuk siap mengikuti pelajaran, terutama pada jam-jam awal pembelajaran. Selain itu, yel-yel juga sangat efektif membangun kekompakan dan kerja sama dalam tim.

Selain pelatihan yel-yel dalam pengabdian masyarakat ini juga melatihkan jenis ice breaking tepuk tangan. Jenis ice breaking ini adalah jenis yang paling sering digunakan oleh para tenaga pendidik. Teknik tepuk tangan merupakan teknik ice breaking yang paling mudah dilakukan, karena tidak memerlukan persiapan yang membutuhkan banyak waktu. Seorang guru hanya perlu memodifikasi sedikit jenis yang ada atau membuat sendiri model-model tepuk tangan yang sudah ada. Beberapa variasi tepuk tangan meliputi

a) Kata balas tepuk tangan

Kata balas tepuk tangan dilakukan dengan cara setiap kata yang diucapkan oleh guru direspon siswa dengan melakukan tepuk tangan dalam jumlah tertentu. Jumlah tepuk tangan tergantung kesepakatan bersama antara guru dan siswa yang bersangkutan. Ada banyak jenis respon yang diberikan oleh siswa, mulai dari yang hanyasekedar tepuk tangan sampai dimodifikasi dengan konten materi pelajaran.

b) Tepuk balas tepuk

Tepuk balas tepuk merupakan variasi ice breaking jenis tepuk tangan yang sangat mudah. Dalam prakteknya, hanya dibutuhkan kesepakatan-kesepakatan dengan siswa tentang model dan jumlah tepuk tangan ataupun variasi lain yang memungkinkan siswa lebih senang.

c) Tepuk tangan balas gerak tubuh

Jenis tepuk tangan dibalas gerakan atau gerak tubuh dibalas dengan tepuk tangan menuntut 
konsentrasi dari siswa, namun sangat mengasyikkan untuk dijadikan ice breaking.

Selain Yel-yel dan permaina tepuk, simulasi yang dilakukan oleh peserta pelatihan adalah melakukan permainan (games). Permainan adalah jenis ice breaking yang paling membuat siswa heboh. Siswa akan muncul semangat baru yang lebih saat melakukan permainan. Dengan permainan akan mampu membangun konsentrasi anak untuk dapat berpikir dan bertindak lebih baik dan lebih efektif. Permainan merupakan kegiatan yang paling digemari oleh semua orang. Bukan saja bagi anak-anak, namun juga bagi para siswa didik dewasa. Hal-hal yang harus diperhatikan guru dalam memilih games yang akan digunakan sebagai ice breaking menurut (Sunarto,2012) antara lain:

a) Faktor keselamatan

Faktor keselamatan harus menjadi prioritas utama saat akan menentukan jenis games yang akan dipilih. Guru harus memilih jenis games yang aman terhadap keselamatan siswa

b) Faktor waktu

Banyak sekali jenis games yang dapat dilakukan bersama guru dan siswa didik. Namun demikian pilihlah games yang tidak membutuhkan terlalu banyak waktu.

c) Faktor peralatan

Games yang dipilih hendaknya yang membutuhkan peralatan sederhana yang selalu tersedia di dalam kelas, misalnya pensil, buku, kursi, kertas dan sebagainya.

d) Faktor edukasi

Apapun yang dilakukan guru terhadap siswa adalah dalam rangka pendidikan dan pembelajaran. Nilai-nilai edukatif yang bisa diperoleh dari pelaksanaan games, yaitu terciptanya kekompakan, kerja sama, kemandirian, konsentrasi, kreativitas, dan sebagainya.

Dalam mengikuti kegiatan training para guru bersemangat dan menegikuti dengan baik. Pada saat praktik penerpan ice breaking para guru juga nampak antusias.

\section{KESIMPULAN}

Setelah dilaksanakan Program Pengabdian Masyarakat, dapat disimpulkan sebagai berikut. Sebelum pelatihan, dilakukan survei pelaksanaan pembelajaran di MI Silahul Muslimin Dusun Persen Desa Kedungasri Kecamatan Tegaldlimo Kabupaten Banyuwangi. Dari hasil observasi awal diperoleh data permasalahan mitra yaitu pembelajaran selama pandemi covid19 dilakukan dalam tatap muka terbatas (PTM) dan menggunakan metode drilling. Kegiatan awal pembelajaran guru hanya memberikan apersepsi, guru belum melakukan motivasi terhadap siswa. Ketika proses pembelajaran berlangsung siswa lebih banyak melakukan aktifitas mengerjakan soal yang diberikan guru. Jika beberapa siswa telah menyelesaikan tugasnya terlihat tidak ada kegiatan hanya dihimbau untuk menunggu teman yang belum selesai. Terlihat siswa ada yang melamun, atau sesekali menggangu teman yang belum selesai mengerjakan tugas. Sehingga dalam mengikuti pembelajaran siswa sering mengalami kebosanan dan kurang bersemangat dan cenderung pasif. Dalam hal ini diperlukan inovasi dalam pembelajaran. Melalui pelatihan ice breaking pada para guru diharapkan pembelajaran lebih hidup dan menumbuhkan semangat siswa dalam pembelajaran dilakukan dengan waktu yang terbatas.

Proses pelatihan diikuti oleh 15 guru MI Silahul Muslimin Dusun Persen Desa Kedungasri Kecamatan Tegaldlimo Kabupaten Banyuwangi. Pelatihan dilakukan dengan metode Selama kegiatan guru mengikuti pelatihan dengan tertib dan melakukan simulasi ice breaking dengan penuh semangat. Setelah pelatihan dilakukan, peserta pelatihan diberikan angket dan diperoleh hasil bahwa peserta banyak yang menjawab sangat setuju bahwa (1) materi pelatihan yang diberikan sesuai yang dibutuhkan peserta, (2) metode pelatihan yang digunakan sesuai dengan jenis pelatihan, (3) kemampuan instruktur pelatihan dalam memberikan pelatihan sudah sesuai harapan, (4) peserta memiliki antusias yang tinggi dalam pelatihan, (5) pelatihan dapat memberikan penyegaran pikiran untuk peserta 6) peserta mampu menyerap ilmu pengetahuan yang diberikan setelah mengikuti pelatihan, (7) peserta mampu menyerap ilmu keterampilan yang diberikan setelah mengikuti pelatihan, (8) terdapat relevansi kondisi saat ini dengan pelatihan yang telah dilaksanakan. 


\section{UCAPAN TERIMA KASIH}

Tim pengabdian kepada masyarakat mengucapkan terimakasih kepada kepala sekolah dan para guru MI Silahul Muslimin Dusun Persen Desa Kedungasri Kecamatan Tegaldlimo Kabupaten Banyuwangi yang telah memberikan dukungan sepenuhnya dalam proses pelatihan dan pendampingan melalui pelatihan training ice breaking serta telah senantiasa mengikuti semua rangkaian acara dalam kegiatan pelatihan dengan baik dan tertib.

\section{DAFTAR PUSTAKA}

Achmad, F. (2010). Ice Breaking dalam Proses Belajar Mengajar. Surabaya: Universitas PGRI Adi Buana Surabaya.

Kadir, A., \& Asrohah, H. (2015). Pembelajaran tematik. Raja Grafindo Persada.

Keputusan bersama Menteri Pendidikan dan kebudayaan, menteri agama, menteri kesehatan dan menteri dalam negeri tentang panduan penyelenggaraan pembelajaran di amasa pandemi coronavirus disease 2019 (covid-19)

Syah, M. (2013). Psikologi Pendidikan. Bandung: Remaja Rosdakarya.

Said, M. (2010). Ice Breaker Games-Kumpulan Permainan Penggugah Semangat. Yogyakarta: Andi Offset.

Sigit, S. (2013). Nyalakan kelasmu 20 Metode mengajar dan Aplikasinya. Jakarta: PT. Gramedia.

Sunarto. (2012). Ice Breaker dalam Pembelajaran Aktif. Surakarta: Yuman Pressindo

Tohirin. (2011). Psikologi Pembelajaran Pendidikan Agama Islam. Jakarta: Rajawali

Setiawan, A. (2012). Ice Breakers For Teachers. Sidoarjo: Filla Press

Yonny, A. (2012). Cara Cerdas Membangkitkan Semangat Belajar Siswa. Yogyakarta: PT. Citra Aji Parama 